a hyperbola. Similar curves were obtained in respect of the nitrogen content of the leaves and the effect of nitrogen fertilizers. Phosphoric acid also revealed the same principal rule, namely, an approximately inverse relation between the concentration of phosphorus in the leaves and the increase in yield after treatment of the soil with superphosphate. Moreover, the leaf analysis demonstrated the co-operation of the nutrient factors according to the principle of limiting factors.

An example of the interaction of potassium and phosphorus is illustrated by Fig. 3: if the soil suffers from phosphorus deficiency (= low P-value in the leaves), fertilization with potassium salt alone will yield less than if superphosphate were added. Similarly, leaf analysis enables us to decide whether superphosphate will pay without simultaneous nitrate fertilization or not.

The advantages of leaf analyses, compared with soil analysis, are summed up as follows : the plant will indicate more precisely the availability of the

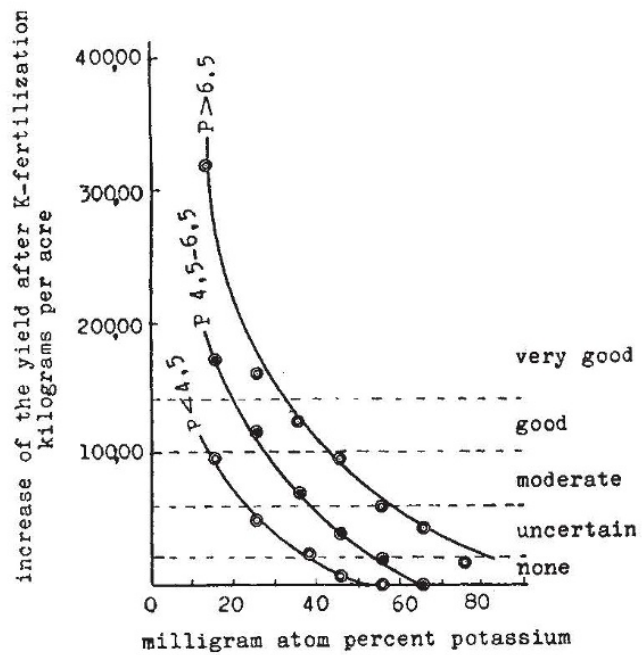

Fig. 3. PROBARLE GFFEOT ON THE YIELD OF FRRTILIZATION WITH 60 KGM. 40 PER CENT POTASSIUM SALT PER ACRE. A LOW CONTENT OF POTASSIUM IN THE LEAVES INDIOATES GOOD RFSULTS,
HITH CONTHNTS LESS GOOD, ETC. INOREASING SUPPIY OF PHOSPHORUS RAISFS THE UTLIZATION OF POTASSIUM.

nutrient salts in the soil, because it has its own methods of extraction. Moreover, leaf analysis gives not only an instantaneous picture of the situation in the soil, but also sums up the extraction of salts during a period of several weeks, for the samples are taken at a stage when the vegetative parts of the plant are fully grown but still vigorous. This viewpoint is important, not only in respect of the availability of nitrogen, but also in respect of potassium, phosphoric acid and calcium, which components are extracted from the soil by the joint action of the roots and the soil micro-organisms.

A drawback connected with the method of leaf analysis is the variability of the environmental factors, especially rainfall and temperature. As the samples are taken at a comparatively early date, variations in the second part of the season have no influence. But a dry summer tends to raise the concentration of nutrient elements in the leaves, whereas a wet period influences the development in the opposite direction. The experience of the last five summers, with their large amplitude of temperature and rainfall, teaches that samples taken on the same plot reveal certain variations in respect of leaf analysis, but these variations are reasonably limited. The method of leaf analysis will thus probably be of some value in teaching the farmer how to economize with mineral fertilizers and how to use them in the right proportions.

' Lundegårdh, H., "Die Nährstoffaufnahme der Pfianze", Jena, 1932 ; Ann. Agric. Coll. Sweden, 9, 127 (1941).

sagatu, H., and Maume, L., Ann. Ecole Nat. Agr. Montpellier, Prem. mém., 20, 219 (1930).

s Thomas, W., Plant Physiol., 12, 571 (1937).

\section{PLANNING POST-WAR BRITAIN*}

THE Institution of Municipal and County Engineers has prepared a report in consequence of the Government's acceptance of the principle of planning on a national scale. The national plan should, it is suggested, be prepared on broad lines by a ministerial department which should lay down general principles for the whole of Great Britain. These should deal with policy, standards and national details, such as communications, zoning as affecting national parks, preservation of mountains, moorlands, recreational coastline, forestry, etc., and electricity, gas and water supply. Under policy would come such matters as enabling legislation, agricultural systems, distribution of industry and of population, while under standards would be considered minimum conditions of housing, industrial and commercial zoning and lay-out and recreational facilities.

Local authorities, it is suggested, should remain responsible for detailed planning, together with allied matters such as drainage, road-making, bridge-building and housing, but to secure co-ordination of detail over wider areas there should be a statutory obligation on local authorities within a particular region to collaborate in the preparation of a unified scheme. The boundaries of regional schemes should be defined by the central authority in consultation with local authorities. They should be fixed more with the view of community of interest and topographical considerations than of local government areas.

A major section of the report is then devoted to national and regional communications, and a Government investigation of the whole subject in all its bearings on the life of the community is recommended as a basis for planning. In regard to railways, it is recommended that any necessary financial or other assistance should be provided without restricting other forms of transport. More use of canals and water-ways for the transport of heavy goods is recommended to relieve congestion on railways and roads, but the major feature of this section is the recommendation regarding the provision of high-speed motor-ways - single-purpose roads restricted to motor vehicles-a proposal which was urged with great force by Lord Sempill in the House of Lords debate on November 19.

Dealing with the development of built-up areas as part of a complete town plan, the report insists that the planning authority for a district must decide the type of buildings on a site and lay down the standards for the widths of roads, heights of buildings, general style of architecture, housing density, etc. The complete plan of any town or the redevelopment of particular districts must keep in mind the provision of

* Post-war Planning and Reconstruction. Pp. 48. (London: Institution of Municipal and County Engineers, 1942.) 18. 
adequate communications and parking facilities, preservation of the historic character of the town, ancient monuments, well-known thoroughfares, etc., spaciousness in suitable districts combined with compactness of design on building sites, and grouping of eivic buildings, shopping, museums and recreational facilities according to their character and demand. In regard to the establishment of satellite towns, the report suggests that the first step should be an analysis of residential requirements. This should include a survey of existing residential development and the extent of over-crowding, the consideration of types of residential development required and maximum densities, and a survey of reservations of land at present used for residential purposes, with the object of distributing the existing industrial or business development and providing the needed areas of open space, playing fields, etc.

On the establishment of new industries in existing towns the report urges that factors such as the more equitable distribution of the world's raw materials, the state of Great Britain's heavy industries due to increasing production in foreign countries and a policy of emigration to develop the resources of the Empire make the proper distribution of existing industries more important than the establishment of new ones. New industries should be located in suitable places throughout the country in or adjacent to existing towns which have suffered from depression, the environs and needs of which have been properly planned and considered beforehand. Care should be taken that agricultural life is not disturbed and that agriculture is given its rightful place as a vital industry, the rural surroundings of a town being regarded as a natural and essential complement to a well-balanced urban community. The suitability of light industries for the fringes of country towns once again receives recognition, while the serious monetary problems which the law at present offers in planning agricultural belts and parkways between existing towns and future growths is firmly emphasized in a plea for enactment of a bolder and more equitable policy. In particular, a planning authority should no longer be liable to compensate owners of agricultural land for the loss of potential development value which never existed.

Attention is then directed to problems of regional drainage, both of surface-water and of foul-water drainage, including the purification of sewage and trade waste. The boundaries of the regional authorities undertaking these matters should be dictated by geographical considerations and would not necessarily coincide with the boundaries set up for the purpose of unifying local government on a regional basis. Similarly, while it is recommended that the water policy of Great Britain should be guided nationally by a central authority, directly responsible to Parliament, with power to control and co-ordinate all water sources, the central authority's administrative powers should be devolved on regional bodies, also possessing statutory authority, and controlling areas related to the areas of the respective watersheds grouped with suitable districts. A comprehensive and accurate investigation of all water resources, whether above or below ground, the consolidation and modernization of water legislation, including the simplification of the control of rivers, and an overhaul of the present system of rating water undertakings are further recommendations.

In the section on desirable standards for buildings, buildings and light angles, the report has special weight. The Institution of Municipal and County Engineers has frequently had to protest to the building by-laws section of the Ministry of Health at recent weakening of the by-laws relating to building and the forcing of them on unwilling and protesting local authorities, which has resulted in a decrease in structural stability and health protection. Some of the Institution's contentions as to the small factor of safety have been confirmed by the recent disastrous effect of blast, hundreds of yards from single detonations, on the large breeze-block, lath-and-plaster type of building erected under new by-laws, as against the stability of habitations, close to the explosion, erected under old regulations: The report submits that the clauses in future issues of model by-laws should be the result of decisions taken by a representative committee of those affected by such by-laws, including adequate representation of the Institution, having regard to the responsibilities of its members for enforcing such by-laws.

The final section of the report details desirable standards for highways, parkways, services, recreation and industrial development with regard to the preservation of amenities. These are based on the assumptions that a high-speed motor-road policy will be adopted in Great Britain independent of existing highways, with a link to the Continent, and that a national plan will give guidance on the distribution of services. All questions of planning should be controlled by a minister of Cabinet rank. Among these specific proposals are the placing of all signs and advertisements under the control of planning committees with powers for securing the removal of all signs detrimental to amenity, the taxing of all advertising posters according to their size and the licensing of all advertising stations. Street lighting, the provision of adequate car parks and the enforcement of their use, control of woodlands and trees by the Forestry Commission after agreement with the planning authorities and the removal of noxious trades from the centres of towns to zones the siting of which is not necessarily restricted to the local Parliamentary boundaries, are other points which illustrate the way in which this admirable report indicates the action required to implement an effective policy of planning. The extent to which the recommendations endorse those of the Scott and the Uthwatt Reports is notable.

\section{HEALTH SERVICES IN GREAT BRITAIN}

$\mathrm{D}^{\mathrm{n}}$ R. JOAN McMICHAEL, speaking on February 21 at a Conference on Health attended by trade union leaders and held at the Conway Hall, London, voiced the dissatisfaction of many trade union officials and workers in the health services of Great Britain at the great loss to the war effort from illness in industry. Apart from the great increase in the incidence of tuberculosis and venereal disease, much of this morbidity is due to colds, influenza and accidents; these were largely attributed to the influx into factories of persons unaccustomed to industrial conditions, and adversely affected by the long hours of shift work in factories. The blackout, the inadequate arrangements for married women, the shortage of doctors and nurses, and anxiety-states due to the War also contribute. To 